\title{
CORONARY HEART DISEASE IN LONDON BUSMEN A PROGRESS REPORT WITH PARTICULAR REFERENCE TO PHYSIQUE \\ BY
}

\author{
J. A. HEADY, J. N. MORRIS, AND A. KAGAN \\ Medical Research Council's Social Medicine Research Unit, The London Hospital, \\ AND \\ P. A. B. RAFFLE \\ Medical Department, London Transport Executive
}

The incidence of coronary heart disease (CHD) is less in the middle-aged conductors of London's double-decker buses than in the drivers of the same age. In particular, the "sudden death" rate of conductors under 50 is one-third that of drivers (Morris, Heady, Raffle, Roberts, and Parks, 1953; Morris and Raffle, 1954). By using information on sizes of uniforms, Morris, Heady, and Raffle (1956) showed also that the girth of conductors was less than that of drivers in each 5-year age group from 25-29 to 60-64.

This paper brings the evidence up to date and presents new information. Data about the rate of occurrence of all first clinical attacks in the two occupations are presented for 4 years, and about sudden deaths for 10 years, 1949-58.

The information about the size of uniforms covers a larger sample of garages and also compares drivers who had first been conductors with those recruited directly to driving. Direct physical measurements of waist, chest, and skinfold thickness made on samples of working busmen confirm the findings based on uniform size.
Having thus established occupational differences in disease and in physique, evidence is given of the relationship of disease to occupation and physique together. Comparison in terms of direct physical measurements is made between working, and therefore presumably healthy, men on the one hand and men with coronary heart disease on the other, for both conductors and drivers. Finally, an estimate is made of the "sudden death" rate from coronary heart disease in relation to uniform size in an attempt to assess the extent to which the difference in physique between conductors and drivers could conceivably account for the difference in their sudden death rates.

\section{First Attacks of Coronary Heart Disease}

\section{AND OCCUPATION}

Table I shows the rate of occurrence of all first clinical attacks of coronary heart disease in three main

TABLE I

FIRST CLINICAL ATTACKS OF CORONARY HEART DISEASE (AVERAGE ANNUAL RATES PER THOUSAND) 4 YEARS' EXPERIENCE IN LONDON BUS CONDUCTORS AND DRIVERS, MEN AGED 35-64, $1949-50$ AND $1955-56$

\begin{tabular}{|c|c|c|c|c|c|c|c|c|c|c|c|c|}
\hline \multirow{3}{*}{$\underset{\text { Group }}{\text { Age }}$} & \multicolumn{6}{|c|}{ Conductors } & \multicolumn{6}{|c|}{ Drivers } \\
\hline & \multirow{2}{*}{$\begin{array}{c}\text { Average } \\
\text { No. of } \\
\text { Men }\end{array}$} & \multirow[b]{2}{*}{$\begin{array}{c}\text { Angina } \\
\text { Pectoris }\end{array}$} & \multicolumn{2}{|c|}{ "Coronary Thrombosis" } & \multicolumn{2}{|c|}{ Total First Attacks } & \multirow{2}{*}{$\begin{array}{c}\text { Average } \\
\text { No. of } \\
\text { Men }\end{array}$} & \multirow[b]{2}{*}{$\begin{array}{l}\text { Angina } \\
\text { Pectoris }\end{array}$} & \multicolumn{2}{|c|}{ "Coronary Thrombosis" } & \multicolumn{2}{|c|}{ Total First Attacks } \\
\hline & & & $\begin{array}{l}\text { Coronary occlu- } \\
\text { sion, Myocardial } \\
\text { Infarction, etc. }\end{array}$ & $\begin{array}{l}\text { Sudden } \\
\text { Deaths }\end{array}$ & Number & $\begin{array}{l}\text { Rate per } \\
1,000 \text { per } \\
\text { annum }\end{array}$ & & & $\begin{array}{l}\text { Coronary occlu- } \\
\text { sion, Myocardial } \\
\text { Infarction, etc. }\end{array}$ & $\begin{array}{l}\text { Sudden } \\
\text { Deaths }\end{array}$ & Number & $\begin{array}{l}\text { Rate per } \\
1,000 \text { per } \\
\text { annum }\end{array}$ \\
\hline $\begin{array}{l}35-44 \\
45-54 \\
55-64\end{array}$ & $\begin{array}{l}4,033 \\
2,783 \\
1,802\end{array}$ & $\begin{array}{c}(0 \cdot 0) \\
0 \cdot 5) \\
2 \cdot 5\end{array}$ & $\begin{array}{c}(0 \cdot 3) \\
1 \cdot 4 \\
3 \cdot 1\end{array}$ & $\begin{array}{l}(0.1) \\
(0.7) \\
(0.5)\end{array}$ & $\begin{array}{r}6 \\
29 \\
44\end{array}$ & $\begin{array}{l}(0 \cdot 4) \\
2 \cdot 6 \\
6 \cdot 1\end{array}$ & $\begin{array}{l}5,468 \\
5,454 \\
3,400\end{array}$ & $\begin{array}{c}(0 \cdot 1) \\
(0 \cdot 2) \\
1 \cdot 4\end{array}$ & $\begin{array}{l}0.5 \\
1.9 \\
4.4\end{array}$ & $\begin{array}{l}(0 \cdot 2) \\
1 \cdot 0 \\
2 \cdot 0\end{array}$ & $\begin{array}{r}17 \\
68 \\
106\end{array}$ & $\begin{array}{l}0 \cdot 8 \\
3 \cdot 1 \\
7 \cdot 8\end{array}$ \\
\hline $\begin{array}{l}\text { Total } \\
35-64\end{array}$ & $34,470+$ & 0.7 & $1 \cdot 2$ & 0.4 & 79 & $2 \cdot 3$ & $57,286 t$ & 0.5 & $2 \cdot 0$ & 0.9 & 191 & $3 \cdot 3$ \\
\hline
\end{tabular}

Notes: In all the Tables, unless otherwise specified, the data refer to the Central Buses, Trams, and Trolley-buses of the London Transport Executive, and rates where the number of deaths or cases is less than 10 are in brackets.

Medical diagnoses were obtained from general practitioners' and hospital and other specialists' certificates, and from the London Transport medical officers, who examine all men certified to be suffering from heart disease and certain "suspect" labels and all men whose absence for any cause exceeds 28 days before their return to work. Death certificates were available and, for almost every "sudden" death, the result of a post mortem examination.

tThese figures give the total man-years of exposure in the two occupations. 
clinical types: angina pectoris, coronary occlusion and myocardial infarction which was not immediately fatal, and "sudden death", i.e. death within 3 days of the onset of the first clinical attack. The comparison is between male conductors and drivers aged 35-64, of London's double-decker central buses, trams, and trolley-buses, and refers to the four years 1949-50 and 1955-56. The Table shows a lower first attack rate amongst the conductors in each age group if all three main types are considered together. This difference between the two occupations is, however, most marked for the sudden death rate, while the attack rate for angina pectoris is in fact greater at ages 45-64 in conductors than in drivers. *

If "coronary thrombosis" is taken to include sudden deaths as well as coronary occlusion, myocardial infarction, it will be seen that the combined rates are lower for conductors than for drivers. The difference is clearer than for all first attacks, but not so clear as for sudden deaths alone. $\dagger$

\section{"Sudden Death" and Occupation}

Table II shows, for the 10 years $1949-58$, sudden death rates from coronary heart disease in drivers and male conductors aged 35-64 years, based on a total of more than 200,000 man-years of experience.

The lower sudden death rate amongst conductors shown in Table $I$ is confirmed in this 10-year experience. In round numbers the conductors' mortality is about half that of drivers. The difference is more noticeable at ages under 50 .

\footnotetext{
* The numbers are too small to establish a statistically significant difference between conductors and drivers for the angina rate. The proportion of all first attacks which present as angina pectoris is, however, significantly higher in conductors than in drivers at ages 55-64 $\left(P<\cdot 01 ; \chi^{2}=7 \cdot 6\right)$.

+ Rosenman and Friedman (1958) have noted that there was a higher total incidence of coronary heart disease in the men who worked on the central buses than in those who worked on the trams or trolley-buses as reported by Morris and others (1953). Moreover, the total incidence in the central bus conductors was higher than that in the drivers of trams and trolley-buses. Examination of the new data included in the present report together with the earlier data confirms the general finding that rates are higher for central buses than for trams and trolley-buses, though the difference is not significant $(P>0.05)$. The excess in central bus conductors compared with tram and trolleybus drivers is, however, due to the excess of angina pectoris which has been shown above to be commoner in conductors. The rate of sudden death, and the rate of infarction that was not immediately fatal, are both higher in tram and trolley-bus drivers than in central bus conductors.

The reason for the excess in central buses is obscure. It cannot be explained, as Rosenman and Friedman would have it, on the grounds that the central buses are "down-town" and the trams and trolley-buses "suburban". The trams (which were withdrawn during 1950-52) used to operate in some of the most congested areas of London while the so-called central buses operate over large areas which are at least as "suburban" as the tram and trolley-bus areas.
}

TABLE II

SUDDEN* DEATHS FROM CORONARY HEART DISEASE 10 YEARS' EXPERIENCE IN LONDON BUS CONDUCTORS AND DRIVERS, MEN AGED 35-64, 1949-58

\begin{tabular}{|c|c|c|c|c|c|c|}
\hline \multirow[b]{2}{*}{$\begin{array}{c}\text { Age } \\
\text { Group } \\
\text { (yrs) }\end{array}$} & \multicolumn{3}{|c|}{ Conductors } & \multicolumn{3}{|c|}{ Drivers } \\
\hline & $\begin{array}{c}\text { Average } \\
\text { No. of } \\
\text { Men }\end{array}$ & $\begin{array}{l}\text { Sudden * } \\
\text { Deaths }\end{array}$ & \begin{tabular}{|c|} 
Rate per \\
1,000 \\
per \\
annum
\end{tabular} & $\begin{array}{c}\text { Average } \\
\text { No. of } \\
\text { Men }\end{array}$ & $\begin{array}{l}\text { Sudden * } \\
\text { Deaths }\end{array}$ & $\begin{array}{c}\text { Rate per } \\
1,000 \\
\text { per } \\
\text { annum }\end{array}$ \\
\hline $\begin{array}{l}35-44 \\
45-54 \\
55-64\end{array}$ & $\begin{array}{l}3,747 \\
2,647 \\
1,651\end{array}$ & $\begin{array}{r}4 \\
17 \\
22\end{array}$ & $\begin{array}{c}(0 \cdot 1) \\
0 \cdot 6 \\
1 \cdot 3\end{array}$ & $\begin{array}{l}5,010 \\
5,075 \\
3,250\end{array}$ & $\begin{array}{l}23 \\
51 \\
75\end{array}$ & $\begin{array}{l}0 \cdot 5 \\
1 \cdot 0 \\
2 \cdot 3\end{array}$ \\
\hline $\begin{array}{r}35-49 \\
50-64\end{array}$ & $\begin{array}{l}5,220 \\
2,825\end{array}$ & $\begin{array}{r}9 \\
34\end{array}$ & $\begin{array}{c}(0 \cdot 2) \\
1 \cdot 2\end{array}$ & $\begin{array}{l}7,613 \\
5,722\end{array}$ & $\begin{array}{r}43 \\
106\end{array}$ & $\begin{array}{l}0.6 \\
1.9\end{array}$ \\
\hline $\begin{array}{l}\text { Total } \\
35-64\end{array}$ & $80,452 t$ & 43 & $0 \cdot 5$ & $133,349 t$ & 149 & $1 \cdot 1$ \\
\hline
\end{tabular}

*Deaths within 3 days of the onset of the first clinical episode.

tThese figures give the total man-years of exposure, in the two occupations.

\section{PhysiQue AND OCCUPATION}

Earlier observations made in 1954 on uniform sizes of bus conductors and drivers aged 25-64 (Morris and others, 1956) have now been extended to cover five central bus garages and three trolley-bus depots; and for the age group 55-64, a further three bus garages and two trolley-bus depots. These new observations refer to 1958 and bring the total number of men concerned up to 1,856 conductors and 2,673 drivers. The information available is the trouser size and jacket size for each man. Each size is made for a man with certain measurements (height, waist, and chest) but these measurements are not the exact measurements of the men to whom the garments are issued; nor, even if they were, would they be the ideal measurements for a scientific study of physique. They are tailors' measurements, and make an allowance for comfort of fit. Thus, a different waist measurement will usually be returned when a man is measured for a jacket compared with that used for his trousers. The waist measurement used in the present analysis is the measurement obtained from the trouser size, and the chest measurement that obtained from the jacket size. It was assumed that a man would reject a pair of trousers unless at the least they fitted reasonably at the waist, and a jacket if it was not roughly right across the shoulders and chest. Records of uniforms are amended each time a new one is issued.

Table III (opposite) shows the results for the trouser-waist measurements and Table IV (opposite) for the jacket-chest. In each Table the percentages at both ends of the scale are shown.

Table III shows that at each age there were fewer conductors than drivers with a $38^{\prime \prime}$ waist or greater and more conductors than drivers with a $32^{\prime \prime}$ waist or 
TABLE III

TROUSER-WAIST MEASUREMENTS OF UNIFORMS OF LONDON BUS CONDUCTORS AND DRIVERS, MEN AGED 25-64, 1954 and $1958^{*}$

\begin{tabular}{|c|c|c|c|c|c|c|}
\hline \multirow{2}{*}{$\begin{array}{l}\text { Age Group } \\
\text { (yrs) }\end{array}$} & \multicolumn{2}{|c|}{ Number of Men } & \multicolumn{2}{|c|}{$\begin{array}{c}\text { Percentage with Trouser-waist } 32^{\prime \prime} \\
\text { or Less }\end{array}$} & \multicolumn{2}{|c|}{$\begin{array}{c}\text { Percentage with Trouser-waist } 38^{\prime \prime} \\
\text { or More }\end{array}$} \\
\hline & Conductors & Drivers & Conductors & Drivers & Conductors & Drivers \\
\hline $\begin{array}{l}25-29 \\
30-34 \\
35-44 \\
45-54 \\
55-64\end{array}$ & $\begin{array}{l}269 \\
238 \\
493 \\
446 \\
410\end{array}$ & $\begin{array}{l}184 \\
272 \\
656 \\
746 \\
815\end{array}$ & $\begin{array}{l}73 \\
55 \\
54 \\
40 \\
29\end{array}$ & $\begin{array}{l}52 \\
46 \\
38 \\
18 \\
11\end{array}$ & $\begin{array}{l}1 \cdot 9 \\
2 \cdot 5 \\
7 \cdot 7 \\
13 \\
21\end{array}$ & $\begin{array}{l}8 \cdot 7 \\
11 \\
16 \\
32 \\
44\end{array}$ \\
\hline Total 25-64 & 1,856 & 2,673 & - & - & - & - \\
\hline
\end{tabular}

* The measurements here analysed are for all the men of the relevant ages on the books of certain garages on a chosen day. The data for three garages ( 2 bus and 1 trolley-bus) are for January 1,1954 . The data for a further five garages ( 3 bus and 2 trolley-bus) are for January, 1958. The data for ages 55-64 include also yet five more garages ( 3 bus and 2 trolley-bus) also for January $1,1958$.

TABLE IV JACKET-CHEST MEASUREMENTS OF UNIFORMS OF
LONDON BUS CONDUCTORS AND DRIVERS, MEN AGED 25-64, 1954 and 1958*

\begin{tabular}{c|c|c|c|c}
\hline $\begin{array}{c}\text { Age } \\
\text { Group } \\
\text { (yrs) }\end{array}$ & \multicolumn{2}{|c|}{$\begin{array}{c}\text { Percentage with Jacket- } \\
\text { chest 36" or Less }\end{array}$} & \multicolumn{2}{|c}{$\begin{array}{c}\text { Percentage with Jacket- } \\
\text { chest 40" }\end{array}$} \\
\cline { 2 - 5 } or More
\end{tabular}

*The measurements here analysed are for the same men as in Table III.

less. Table IV shows the corresponding finding in terms of jacket-chest.

It will be seen that:

(1) The men's girth increased with age in both occupations.

(2) The girth of conductors was less than that of drivers.

(3) The difference between conductors and drivers was present in every age group, even the youngest; and the difference was as clear at $25-29$ as at $55-64$.

\section{Differences IN HeIGHT}

In the earlier paper the percentage of men with large trouser-waists and jacket-chests were "standardized" or "adjusted" for height. That is to say, the fact that, on the average, drivers are taller than conductors (in small part because conductors over $6 \mathrm{ft}$ tall are not recruited) was taken into account in the calculations. Since this correction made so little difference it has not been repeated. Fig. $1 \mathrm{~A}$ and $\mathrm{B}$ (overleaf) shows, for the 1954 data, that the difference in girth was independent of differences in height. The men are divided into three height groups (based on uniform sizes) $-5^{\prime} 10^{\prime \prime}$ and over, 5' $8^{\prime \prime}$ and 5'9", and $5^{\prime} 7^{\prime \prime}$ and under. Within each of these, and for every 10-year age group, with one exception, the percentage of conductors with a 38" trouser-waist or more was smaller than the corresponding percentage for drivers (Fig. 1A). Conversely (Fig. 1B), the percentage of conductors with a $32^{\prime \prime}$ trouser-waist measurement or less was greater than the corresponding percentage for drivers (again with one exception).

The corresponding results were true for jacketchest measurements of $40^{\prime \prime}$ or more and of $36^{\prime \prime}$ or less. Differences between drivers and conductors in height are therefore not important in these comparisons of girth.

\section{Confirmation from Clinical Measurements}

To test the use of uniform sizes as a method for comparing the physique of groups, and also to find out whether the difference between the uniform sizes of drivers and conductors might have been the result of a tendency on the part of drivers to take a more loosely fitting garment because they sit down while on duty and need room to manipulate a large steering wheel, whereas conductors might prefer a closer fit, information from another inquiry conducted by this Unit was used.

Since 1956 every case of coronary heart disease in conductors and drivers has been notified to us by the London Transport Executive and "matched" by six "controls" from his work-mates at the same garage. The men were also matched for age, job, and length of service. Controls were otherwise chosen at random, and were presumably healthy; at any rate they were working. If six such men could not be found we had to accept fewer. (The choice of controls from amongst a man's own work-mates was made in order to increase motivation for a high response. 93 per cent. of the men approached in fact agreed to be 


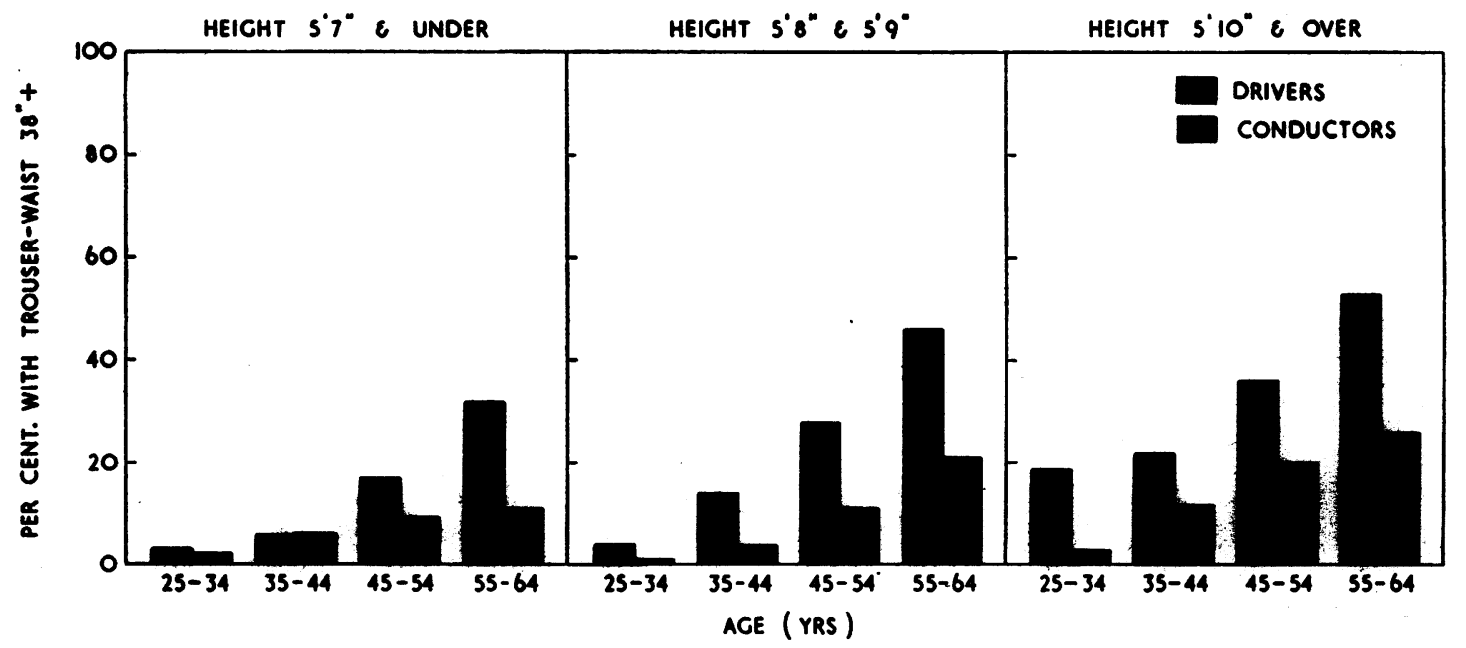

Fig. 1A.-Percentage of conductors and drivers with trouser-waist of $38^{*}$ or more in three height groups*. London Transport Executive, 1954. Men aged 25-64.

${ }^{*}$ Note: The numbers of men in the three height groups were as follows:

\begin{tabular}{|c|c|c|c|c|c|}
\hline \multicolumn{4}{|c|}{ Height } & Conductors & Drivers \\
\hline $\begin{array}{l}5^{\prime} 7^{\prime \prime} \text { and Under } \\
5^{\prime} 8^{\prime \prime} \text { and } 5^{\prime} 9^{\prime \prime} \\
5^{\prime} 10^{\prime \prime} \text { and Over }\end{array}$ & $\begin{array}{l}\cdots \\
\cdots\end{array}$ & $\begin{array}{l}\cdots \\
\cdots\end{array}$ & $\begin{array}{l}\cdots \\
\cdots \\
\cdots\end{array}$ & $\begin{array}{l}384 \\
415 \\
195\end{array}$ & $\begin{array}{l}317 \\
543 \\
416\end{array}$ \\
\hline Total & $\cdots$ & $\ldots$ & $\ldots$ & 994 & 1,276 \\
\hline
\end{tabular}

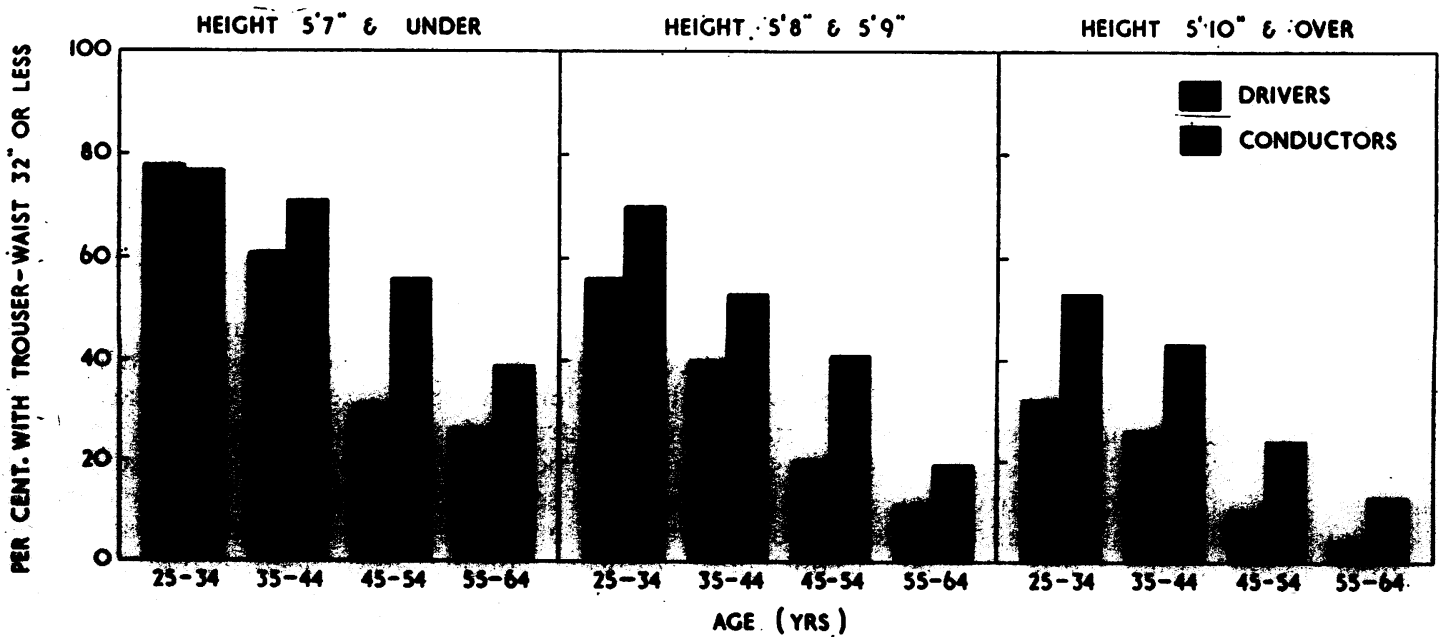

Fio. 12.-Percentage of conductors and drivers with trouser-waist of 32 " or less in three height groups. London Traneport Executive, 1954. 
examined.) These men were visited at the garage by one of us, A.K., and examined clinically. Certain measurements were taken to determine somatotype, including measurements of waist and chest. At the time these measurements were taken no information was available about uniform sizes, but later it occurred to us to collect this information and to compare the clinical measurements with the trouser-waist and jacket-chest measurements of the most recent uniforms issued to the same men. All men examined up to a certain date were taken. There were 121 conductors and 244 drivers.

The results were encouraging. As was to be expected, the clinical measurements were smaller on average than the measurements of the uniforms, since there has to be some "slack" for comfort in wear. There were a few anomalies where the man's clinical measurement was greater than the corresponding uniform measurement; this, we assumed, was either because of error or because a man might choose to take a uniform which fitted him in certain important respects and have it altered in others if there were no standard size to fit him. The correlation between the uniform trouser-waist measurement and the clinical waist measurement was $\mathbf{0 . 8 8}$ for conductors and 0.86 for drivers; between the uniform jacket-chest measurement and the clinical chest measurement it

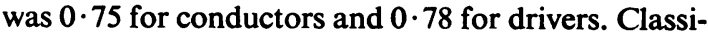
fication of groups of busmen in terms of uniform measurement is not therefore likely to be misleading. Nor was there any apparent bias in the issue of uniforms-i.e. no tendency to issue drivers, for instance, with more loosely-fitting garments than conductors -as can be seen from Fig. 2 . In this figure the uniform trouser-waist measurement is shown along the horizontal scale. Uniform trousers are made for men with waists of certain definite sizes, e.g. 32", 34", etc. - there are no fractional values. For each of these trouser-waist sizes, the average clinical waist measurement of the men issued with trousers of that size was calculated for conductors and drivers separately. This is the value shown on the vertical scale. It will be seen that the lines of averages for the drivers and conductors are practically indistinguishable. In other words, there is no tendency for a driver issued with a uniform with a certain trouser-waist measurement to be thinner (or fatter) than a conductor issued with trousers of the same waist measurement. The diagonal

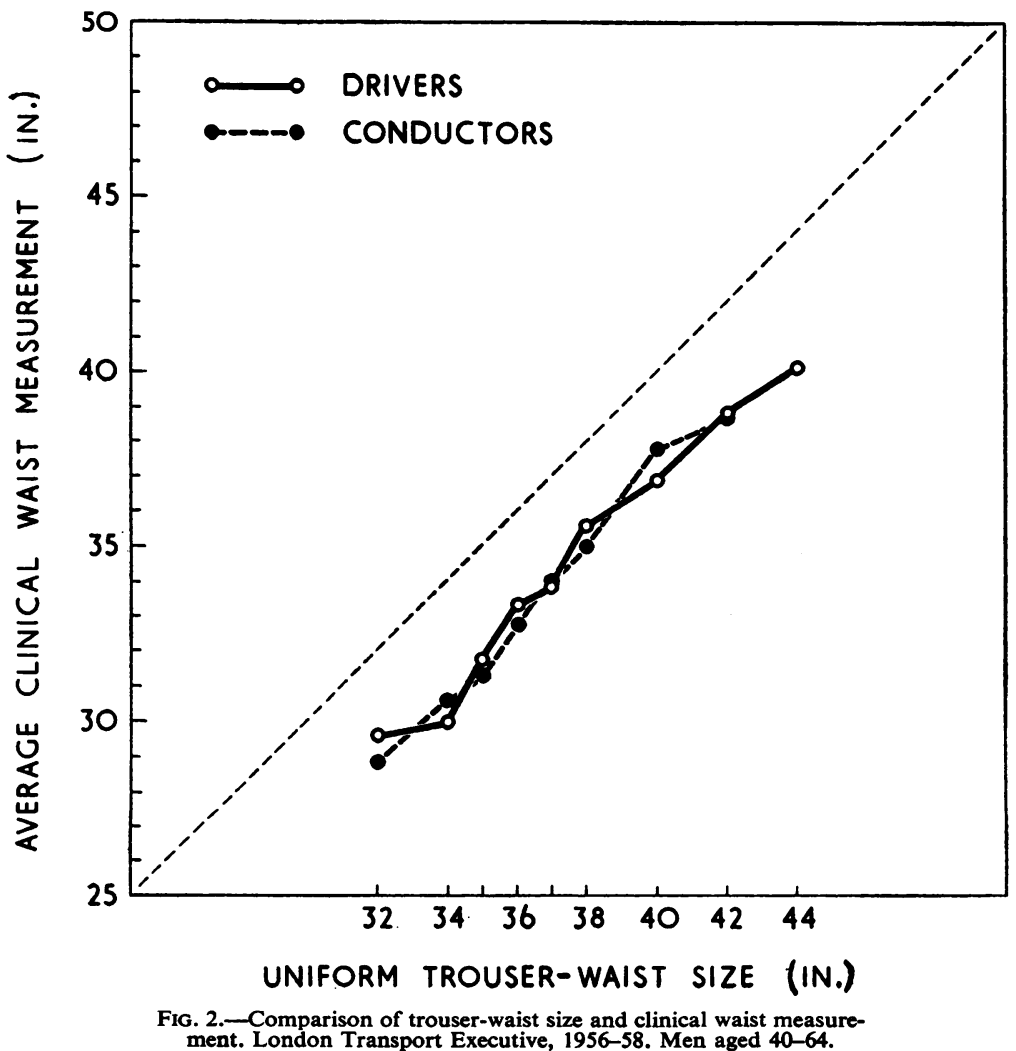


broken line shows where the mean would lie if the trouser-waist measurements were, on average, exactly equal to the clinical waist measurements of the man concerned, and it can be seen that the clinical measurements are on the average 3 "less than the trouserwaist measurements.*

\section{Physique by Direct Clinical Measurement}

The clinical study mentioned above made possible a direct comparison of the clinical measurements of conductors and drivers, but the numbers are adequate

* Setting out this data in more formal terms, the regression coefficients of clinical measurements on uniform trouser waists are: $\begin{array}{ll}\text { Conductors } & +1.047 \\ \text { Drivers } & +0.952\end{array}$

These are not significantly different $(0 \cdot 2>P>0 \cdot 1)$. Using analysis of covariance it can be shown that the difference between adjusted means is $0.43 \mathrm{~cm}$., which is not significant $(P>0.5) ;$ i.e. allowing for the fact that on the average conductors are smaller than drivers, there is significant difference between the two jobs in the clinical measurements of men issued with uniforms of the same size.

The issued with uniforms of the same

$$
\begin{array}{ll}
\text { of estimate are: } & \\
\text { Conductors } & 4.5 \mathrm{~cm} . \\
\text { Drivers } & 5.1 \mathrm{~cm} .
\end{array}
$$

It might be thought more appropriate to look at it from the reverse point of view-i.e., for a given clinical measurement, is a driver given a larger uniform than a conductor? Looked at this way. the regression coefficients of uniform trouser-waist on clinical measurement are:

$$
\begin{array}{ll}
\text { Conductors } & 0.738 \\
\text { Drivers } & 0.783
\end{array}
$$

These are not significantly different $(P \cdot 0 \cdot 5)$. The difference between adjusted means is $0.92 \mathrm{~cm}$. That is to say, the drivers have the larger uniform trouser-waist for a given clinical measurement, but the difuniform trouser-waist for a given clinical

The standard errors of estimate are:
The is not significant $(0 \cdot 1>P=0.05)$

$$
\begin{array}{lr}
\text { Conductors } & 3.8 \mathrm{~cm} \\
\text { Drivers } & 4.6 \mathrm{~cm} \text {. }
\end{array}
$$

In this analysis one conductor whose clinical waist measurement was returned as $189.8 \mathrm{~cm}$. has been omitted, since it was assumed that there was an error. He has also been omitted from Table V. only for ages over 40 . Table $\mathrm{V}$ shows the comparisons for waist and chest measurements and confirms that, at the ages shown, conductors were smaller. Skinfolds were also measured at the clinical examination, and Table $\mathrm{V}$ shows that these measurements of body fat are smaller for conductors than drivers. Heights and weights are also shown, and again the conductors have the smaller measurements. Since weight is related to height (as also are waist and chest measurements) the ponderal index is shown. To the extent that this index eliminates the relationship between height and weight from the comparison it can be seen that conductors were on average lighter for their height than drivers.

There can, therefore, be little doubt that, whatever measure is used, conductors are thinner than drivers.

\section{Conductors, Drivers who Started as Conduc-} TORS, AND DRIVERS WHO STARTED AS DRIVERS

Drivers can be divided into those who joined the service as drivers and those who joined as conductors and subsequently became drivers.

Tables VI and VII (opposite) show that, in terms both of trouser-waist and jacket-chest measurements, drivers recruited from conductors were intermediate between conductors and drivers recruited directly as such. This was true at each age shown, though there are two minor irregularities in the age group 25-34 for small-chested men.

TABLE $\mathrm{V}$

CLINICAL MEASUREMENTS OF CONDUCTORS AND DRIVERS

\begin{tabular}{|c|c|c|c|c|c|c|c|c|c|}
\hline \multirow{2}{*}{\multicolumn{4}{|c|}{ Mean Measurements }} & \multicolumn{6}{|c|}{ Age Group (yrs) } \\
\hline & & & & \multicolumn{2}{|c|}{$40-49$} & \multicolumn{2}{|c|}{$50-59$} & \multicolumn{2}{|c|}{$60-64$} \\
\hline & & & & Conductors & Drivers & Conductors & Drivers & Conductors & Drivers \\
\hline $\begin{array}{l}\text { Waist }(\mathrm{cm} .)^{1} \\
\text { Chest }(\mathrm{cm} .)^{2} \\
\text { Skinfold }(\mathrm{mm} .)^{3}\end{array}$ & $\begin{array}{l}\cdots \\
\therefore \\
\therefore \\
\therefore\end{array}$ & $\begin{array}{l}\cdots \\
\cdots \\
\cdots \\
\therefore\end{array}$ & $\begin{array}{l}\cdots \\
\cdots \\
\cdots \\
\cdots \\
\cdots\end{array}$ & $\begin{array}{c}80 \cdot 5 \\
95 \cdot 5 \\
34 \cdot 5 \\
171 \cdot 0 \\
69 \cdot 5 \\
12 \cdot 66\end{array}$ & $\begin{array}{c}86 \cdot 0 \\
97 \cdot 6 \\
43 \cdot 3 \\
172 \cdot 6 \\
73 \cdot 2 \\
12 \cdot 54\end{array}$ & $\begin{array}{c}82 \cdot 1 \\
92 \cdot 5 \\
36 \cdot 1 \\
170 \cdot 5 \\
66 \cdot 3 \\
12 \cdot 80\end{array}$ & $\begin{array}{c}88 \cdot 9 \\
97 \cdot 0 \\
46 \cdot 9 \\
171 \cdot 4 \\
73 \cdot 8 \\
12 \cdot 45\end{array}$ & $\begin{array}{r}83 \cdot 2 \\
90 \cdot 9 \\
34 \cdot 0 \\
167 \cdot 3 \\
64 \cdot 0 \\
12 \cdot 69\end{array}$ & $\begin{array}{c}88 \cdot 2 \\
95 \cdot 8 \\
43 \cdot 8 \\
170 \cdot 4 \\
70 \cdot 6 \\
12 \cdot 52\end{array}$ \\
\hline \multicolumn{2}{|c|}{ Numbers of Men (Range) } & . & .. & $24-25$ & $48-49$ & $68-78$ & $122-134$ & $45-46$ & $112-118$ \\
\hline
\end{tabular}

Sample of London Busmen aged 40-64 Clinical Survey, 1956-59

Notes:

1. Circumference $2^{\prime \prime}$ above pelvic rim, corresponding to position of a "tailor's waist" measurement, but no "slack" allowed. The subject stands relaxed.

2. Circumference at nipple level made at full inspiration. The subject stands and is instructed to expand the chest by breathing in deeply. The steel measure is pulled tight round the chest.
3. A total of three skinfold measurements: subscapular, triceps, and supra-iliac.

4. In trousers and socks but without shoes, minus $1 \mathrm{~kg}$ 5 . Height (in inches) $/ 3 \sqrt{ }$ Weight (in pounds).

Significance of Differences: The differences between conductors and drivers are statistically highly significant for all six measures shown in the Table if account is taken of the consistency of the differences within age groups. 
TABLE VI

TROUSER-WAIST MEASUREMENTS OF UNIFORMS OF CONDUCTORS, DRIVERS WHO STARTED AS CONDUCTORS, AND DRIVERS WHO STARTED AS DRIVERS, 1956 AND 1958, LONDON BUSMEN AGED 25-64*

\begin{tabular}{|c|c|c|c|c|c|c|c|c|c|}
\hline \multirow{2}{*}{$\begin{array}{l}\text { Age } \\
\text { Group } \\
\text { (yrs) }\end{array}$} & \multicolumn{3}{|c|}{ Number of Men } & \multicolumn{3}{|c|}{$\begin{array}{c}\text { Percentage with Trouser-waist } 32^{\prime \prime} \\
\text { or Less }\end{array}$} & \multicolumn{3}{|c|}{$\begin{array}{c}\text { Percentage with Trouser-waist } 38^{\prime \prime} \\
\text { or More }\end{array}$} \\
\hline & Conductors & $\begin{array}{l}\text { Drivers Ex- } \\
\text { Conductors }\end{array}$ & $\begin{array}{l}\text { Drivers who } \\
\text { started as } \\
\text { Drivers }\end{array}$ & Conductors & $\begin{array}{l}\text { Drivers Ex- } \\
\text { Conductors }\end{array}$ & $\begin{array}{c}\text { Drivers who } \\
\text { started as } \\
\text { Drivers }\end{array}$ & Conductors & $\begin{array}{l}\text { Drivers Ex- } \\
\text { Conductors }\end{array}$ & $\begin{array}{c}\text { Drivers who } \\
\text { started as } \\
\text { Drivers }\end{array}$ \\
\hline $\begin{array}{l}25-29 \\
30-34 \\
35-44 \\
45-54 \\
55-64\end{array}$ & $\begin{array}{l}107 \\
135 \\
344 \\
356 \\
348\end{array}$ & $\begin{array}{r}87 \\
96 \\
289 \\
285 \\
312\end{array}$ & $\begin{array}{r}64 \\
66 \\
199 \\
300 \\
407\end{array}$ & $\begin{array}{l}67 \\
53 \\
50 \\
37 \\
29\end{array}$ & $\begin{array}{l}52 \\
46 \\
37 \\
18 \\
12\end{array}$ & $\begin{array}{c}38 \\
39 \\
33 \\
13 \\
9.6\end{array}$ & $\begin{array}{c}3 \cdot 0 \\
2 \cdot 2 \\
8 \cdot 1 \\
13 \\
22\end{array}$ & $\begin{array}{c}8 \cdot 0 \\
7 \cdot 3 \\
17 \\
32 \\
39\end{array}$ & $\begin{array}{l}11 \\
17 \\
18 \\
41 \\
49\end{array}$ \\
\hline Total 25-64 & 1,350 & 1,069 & 1,036 & - & - & - & - & - & - \\
\hline
\end{tabular}

*The measurements analysed in this Table are for the same garages as in Table III, except that one of the three garages in the 1954 sample is excluded. In 1954 no distinction was made between drivers who had been conductors and those who had not. Two of the three garages which were included in the 1954 sample are included in the 1956 sample here analysed.

TABLE VII

JACKET-CHEST MEASUREMENTS OF UNIFORMS OF CONDUCTORS, DRIVERS WHO STARTED AS CONDUCTORS, AND DRIVERS WHO STARTED AS DRIVERS, 1956 AND 1958, LONDON BUSMEN AGED 25-64*

\begin{tabular}{|c|c|c|c|c|c|c|}
\hline \multirow{2}{*}{$\underset{\text { (yrs) }}{\text { Age Group }}$} & \multicolumn{3}{|c|}{ Percentage with Jacket-chest $36^{\prime \prime}$ or Less } & \multicolumn{3}{|c|}{ Percentage with Jacket-chest $40^{\prime \prime}$ or More } \\
\hline & Conductors & $\begin{array}{c}\text { Drivers } \\
\text { Ex-Conductors }\end{array}$ & $\begin{array}{l}\text { Drivers who } \\
\text { started as } \\
\text { Drivers }\end{array}$ & Conductors & $\begin{array}{c}\text { Drivers } \\
\text { Ex-Conductors }\end{array}$ & $\begin{array}{c}\text { Drivers who } \\
\text { started as } \\
\text { Drivers }\end{array}$ \\
\hline $\begin{array}{l}25-29 \\
30-34 \\
35-44 \\
45-54 \\
55-64\end{array}$ & $\begin{array}{l}28 \\
26 \\
31 \\
20 \\
20\end{array}$ & $\begin{array}{c}15 \\
26 \\
17 \\
14 \\
8 \cdot 7\end{array}$ & $\begin{array}{l}17 \\
21 \\
15 \\
7.0 \\
5.9\end{array}$ & $\begin{array}{l}13 \\
13 \\
24 \\
29 \\
35\end{array}$ & $\begin{array}{l}18 \\
21 \\
34 \\
53 \\
55\end{array}$ & $\begin{array}{l}22 \\
33 \\
36 \\
57 \\
62\end{array}$ \\
\hline
\end{tabular}

* The measurements here analysed are for the same men as in Table VI.

The suggestion in the earlier report (Morris and others, 1956) that drivers who had been conductors were similar to those recruited directly is not borne out in the present report on much larger numbers. There seems to be a real difference between the three groups. Hence, though conductors who chose to become drivers may not have been the same in terms of girth as drivers who were recruited directly, they were different from other conductors. In this connexion, it needs to be pointed out that all drivers recruited direct to the service had had driving experience, mainly heavy goods vehicle driving.

To sum up these differences in physique: in terms of uniform size and of direct measurement, conductors, age for age and height for height, had smaller waist and chest measurements than drivers. Skinfold measurements show that conductors also had less body fat than drivers. The difference in uniform size was present even at the youngest ages shown. Further, drivers who started as conductors were intermediate between conductors of the same age who remained conductors and drivers who were directly recruited from previous driving occupations.

\section{Coronary Heart Disease, Physique, AND OCCUPATION}

It is all too easy to assume, because there is evidence of some physical difference between conductors and drivers, that this difference accounts for the difference between the two groups of men in their experience of coronary heart disease (Keys, 1957; Reid, 1958; Brontë-Stewart, 1959). This, of course, is not necessarily so. It is necessary first to establish the relationship between physique and the tendency to suffer from coronary heart disease. This may not be by any means a simple relationship, and, even if it were, the occupational difference might yet be clear when men of similar physique were compared.

\section{Busmen with Coronary Heart Disease compared WITH WORKING BUSMEN}

The simplest way to test the hypothesis that girth, or fatness, is related to the occurrence of coronary heart disease is to compare the measurements of men with coronary heart disease with a group of normal 
healthy men. This we have attempted to do by comparing clinical measurements and skinfold thicknesses of men who have had an attack of coronary heart disease with the "matched controls" discussed earlier. The results are shown in Table VIII.

TABLE VIII

CLINICAL MEASUREMENTS OF PATIENTS WITH CORONARY HEART DISEASE COMPARED WITH MATCHED CONTROLS, LONDON BUSMEN AGED 40-64, 1956-59

\begin{tabular}{|c|c|c|c|}
\hline $\begin{array}{c}\text { Mean } \\
\text { Measurements }\end{array}$ & Grade & \begin{tabular}{|c} 
Patients with \\
Coronary Heart \\
Disease
\end{tabular} & $\begin{array}{l}\text { Matched } \\
\text { Controls }\end{array}$ \\
\hline Waist (cm.) & $\begin{array}{l}\text { Conductors } \\
\text { Drivers }\end{array}$ & $\begin{array}{l}87 \cdot 2 \\
90 \cdot 9\end{array}$ & $\begin{array}{l}84 \cdot 1 \\
88 \cdot 9\end{array}$ \\
\hline Chest (cm.) & $\begin{array}{l}\text { Conductors } \\
\text { Drivers }\end{array}$ & $\begin{array}{l}92 \cdot 3 \\
97 \cdot 4 \\
\end{array}$ & $\begin{array}{l}92 \cdot 9 \\
97 \cdot 3 \\
\end{array}$ \\
\hline Skinfold (mm.) & $\begin{array}{l}\text { Conductors } \\
\text { Drivers }\end{array}$ & $\begin{array}{r}42 \cdot 7 \\
43 \cdot 2 \\
\end{array}$ & $\begin{array}{l}33 \cdot 4 \\
40 \cdot 5\end{array}$ \\
\hline Height (cm.) & $\begin{array}{l}\text { Conductors } \\
\text { Drivers }\end{array}$ & $\begin{array}{l}169 \cdot 0 \\
172 \cdot 2\end{array}$ & $\begin{array}{l}169 \cdot 6 \\
171.9\end{array}$ \\
\hline Weight (kg.) & $\begin{array}{l}\text { Conductors } \\
\text { Drivers }\end{array}$ & $\begin{array}{l}68 \cdot 4 \\
75 \cdot 0\end{array}$ & $\begin{array}{l}66 \cdot 5 \\
73 \cdot 7\end{array}$ \\
\hline Ponderal Index & $\begin{array}{l}\text { Conductors } \\
\text { Drivers }\end{array}$ & $\begin{array}{l}12 \cdot 54 \\
12 \cdot 41\end{array}$ & $\begin{array}{l}12.69 \\
12.46\end{array}$ \\
\hline $\begin{array}{l}\text { Numbers of } \\
\text { Men (Range) }\end{array}$ & $\begin{array}{l}\text { Conductors } \\
\text { Drivers }\end{array}$ & $\begin{array}{l}23-27 \\
31-33\end{array}$ & $\begin{array}{l}112-136 \\
161-175\end{array}$ \\
\hline
\end{tabular}

Significance of Differences. - None of the differences between means of patients and controls is significant at the 0.05 level except for the skinfold where the difference is significant $(0.05>P>0.01)$ for conductors but not for drivers.

The figures shown are for total skinfold: triceps, subscapular, and supra-iliac. For drivers there was no difference between cases and controls for any of the three individual skinfolds but, for conductors, there were significant differences for subscapular $(0.05>P>0.01)$ and supra-iliac $(0.01>P>0.001)$, but not for triceps.

Skinfold thicknesses were transformed using the formula $z=100 \log _{10}$ (reading in $0.1 \mathrm{~mm} .-18$ ), (Edwards, Hammond, Healy, Tanner, and Waterhouse, 1955).

Analysis of variance was used, and the matching variables-age, length of service, and place of work-were thus allowed for. Note:

For definitions, see Table V.

In interpreting this Table, it should be remembered that, in each comparison between cases and controls, differences in the ages, jobs, length of service, and place of work of the men are automatically allowed for because of the method of matching. Discussion is therefore limited to comparison between cases and controls within occupations. Further, Table VIII deals only, so far as the cases are concerned, with men who survived long enough to be measured. This means for all practical purposes that all men who died within a month of the attack are excluded: in particular the rapidly fatal cases, which have been shown (Morris and others, 1953) to comprise some 30 per cent. of new cases, are missing. The Table, therefore, may not be typical of all new coronary cases among busmen. The measurements were taken between about 1 and 6 months after the incident.
With these provisos in mind, it will be seen from Table VIII that the waist and chest measurements of the coronary heart disease patients are not significantly greater than those of the controls, and also that there are no significant differences between patients and controls in height, weight, or ponderal index. On the other hand, skinfold thicknesses are greater for patients than for controls in conductors but not in drivers (see footnote to Table VIII). It is possible that the results for conductors are partly attributable to the disease, since the measurements of patients are made some time after the attack. Conductors will cease their relatively active occupation when they are ill and conceivably could put on fat; it has not been possible to test this notion. Sanders (1959) has shown that, in a group of ordinary healthy men taken from a general practice, all three skinfold measurements were significantly smaller than in men from the same practice who had coronary heart disease, allowance having been made for difference in weight, height, and age. There were no significant differences in terms of weight.*

\section{Sudden Death Rates in Conductors and DRIVERS in RELATION to UNiform Size}

A more direct attempt to show to what extent the differences in physique between conductors and drivers account for the difference between them in mortality from coronary heart disease is contained in Table IX (opposite).

As has been mentioned earlier, the clearest difference between conductors and drivers in their experience of coronary heart disease is in the sudden death rate in early middle age. Table IX therefore shows the sudden death rates in six categories for each of the two occupations-three categories of uniform size (trouser-waist) and two of age (under and over 50), cross-tabulated. It is thus possible to compare directly the sudden death rate of drivers and conductors in the same broad age group and in the same category of waist measurement.

Such a comparison involves certain technical difficulties:

(1) Information about the uniform sizes of drivers who died suddenly in 1949-52 was not available. Hence deaths of drivers in the second part of a period of rising mortality are compared with deaths of conductors over the whole period. (It was necessary to

* Acheson (1961), in a recent study of men aged 65-85 in Dublin, found no significant differences between men with coronary heart disease and controls in height, weight, or skinfold thickness, but there was a difference in ponderal index, the men with coronary heart disease being "stockier". 
TABLE IX

SUDDEN DEATHS OF CONDUCTORS AND DRIVERS, AGED 35-64, IN RELATION TO UNIFORM

London Busmen

Rates per thousand per annum (estimated)

\begin{tabular}{|c|c|c|c|c|c|}
\hline \multirow{2}{*}{$\begin{array}{c}\text { Age } \\
\text { Group } \\
\text { (yrs) }\end{array}$} & \multirow{2}{*}{ Grade } & \multicolumn{4}{|c|}{ Trouser-waist (in.) } \\
\hline & & 32 or Less & $34-37$ & 38 or More & Total \\
\hline \multirow{2}{*}{$35-49$} & Drivers & $\begin{array}{l}0.8 \\
(11)\end{array}$ & $\begin{array}{l}0.5 \\
(10)\end{array}$ & $\begin{array}{l}1 \cdot 0 \\
(9)\end{array}$ & 0.7 \\
\hline & Conductors & $\begin{array}{c}0.2 \\
(5)\end{array}$ & $\begin{array}{c}0.2 \\
(4)\end{array}$ & $\begin{array}{c}0 \\
(0)\end{array}$ & 0.2 \\
\hline \multirow{2}{*}{$50-64$} & Drivers & $\begin{array}{l}2 \cdot 2 \\
(10)\end{array}$ & $\begin{array}{l}1 \cdot 2 \\
(20)\end{array}$ & $\begin{array}{l}2 \cdot 7 \\
(39)\end{array}$ & $2 \cdot 0$ \\
\hline & Conductors & $\begin{array}{l}1 \cdot 4 \\
(12)\end{array}$ & $\begin{array}{l}1 \cdot 0 \\
(14)\end{array}$ & $\begin{array}{l}1 \cdot 3 \\
(7)\end{array}$ & $1 \cdot 2$ \\
\hline \multirow{2}{*}{ Total 35-64 } & Drivers & $1 \cdot 1$ & 0.8 & $2 \cdot 0$ & $1 \cdot 2$ \\
\hline & Conductors & 0.5 & 0.5 & 0.7 & 0.5 \\
\hline
\end{tabular}

* The figures for drivers refer to 1953-58 only.

Notes:

The numbers of deaths in the relevant categories are shown in brackets.

In the age group 50-64, no uniform size was available for one driver and one conductor amongst the men who died suddenly.

The numbers of men in the population with uniform trouser-waists of a certain range were estimated as follows. The number of men in a certain job and of a certain age (e.g. conductors aged 50-64) in the population was multiplied by that proportion in the sample of men of this age and job who had uniform trouser-waists in a certain range (e.g. $32^{*}$ or Less), assuming the sample to be representative of the whole.

consider the deaths of conductors in the whole 10-year period because the numbers were so small.) This might spuriously increase the drivers' rates relative to the conductors'. Calculation, however, shows that this does not matter.

(2) The denominators of the rates are estimated from samples and not complete counts. Sampling errors cannot be calculated since the samples are not random, but the results from different garages and in the two different samples (1954 and 1958) are consistent.

Table IX, nevertheless, shows a clear result. In every one of the six possible comparisons the sudden death rate of conductors is less than that of drivers, though, of course, with such small numbers of deaths by no means all these differences are statistically significant and, indeed, some of them are small. It is clear, therefore, that the difference between conductors and drivers in their sudden death rates, though it may be in part accounted for by differences in physique, is none the less clearly present when such differences have been allowed for.

There is also evidence in Table IX that the relationship between waist measurement and sudden death from coronary heart disease may not be a simple one.
For although the death rates of the "fat" men (38" or More) are nearly all greater than those of the "medium" men ( 34 " -37 "), so also are the rates of the "thin" men (32" or Less).

Similar Tables to Table IX for jacket-chest size are not printed; they show an equally clear difference between conductors and drivers in all possible comparisons.

Analyses of all first attacks together, also not shown, show a lower incidence in conductors than in drivers in five of the six comparisons in terms of trouserwaist, the exception being the "fat" conductors aged 50-64, who have a higher incidence than drivers. In terms of jacket-chest, the conductors have a lower rate in all six comparisons. Numbers are small and few of the differences are significant.

Summing up the interrelationships between coronary heart disease, physique, and occupation:

(1) Differences in waist and chest measurements and skinfold thickness between conductors and drivers seem clear in health.

(2) The only significant difference in physique found between the survivors of coronary heart disease and the controls was that the skinfold measurements for surviving conductors were on average greater than the skinfolds of the control conductors.

(3) The sudden death rates of conductors are lower than those of drivers with similar waist measurements.

\section{Discussion}

The data in this paper refer only to London busmen and the interaction between coronary heart disease, physique, and occupation in these men. A study of bus conductors and drivers would be of limited interest were it not that differences between them in mortality from and incidence of coronary heart disease were the initial observations which led to the setting up of a hypothesis that physical activity of work is a protection against developing the disease.

It is important to stress that the hypothesis about the importance of physical activity does not depend only on the differences observed in conductors and drivers. It has been tested by contrasting the incidence of coronary disease in other occupations which differ in physical activity (postmen as compared with post office telephonists or civil service executive officers or clerks); by using the statistics of occupational mortality for England and Wales, both for 1930-32 
and for 1949-53, and comparing, within social classes, the mortality from coronary disease in three groups of occupations distinguished by the physical activity typically involved in them; by relating the length of history of the disease in men dying of it to the physical activity involved in their work; and by relating ischaemic myocardial scarring on necropsy to occupation in men dying from causes other than coronary heart disease (Morris and others, 1953; Morris and Crawford, 1958). In all these varied tests the hypothesis has been upheld and it is therefore by now independent of the contrast between conductors and drivers.

It is, nevertheless, interesting to study bus conductors and drivers in greater detail and to find out whether they differ in other ways than their experience of coronary disease and their occupation. It is relatively easy to do so since the London Transport Executive have excellent records and encourage further study. Much information is available from the clinical survey of this Unit referred to earlier.

From the data presented in this paper it is clear that the two occupations differ in physique, and that this is true for all ages in the working span. Drivers differ also amongst themselves, those who have been conductors being closer in physique to the conductors than are the drivers who were recruited directly from other driving work. Conductors have lower casual blood pressures, lower blood lipid values, and lower haemoglobin levels than drivers (Morris, 1959; Kagan, 1960). On the other hand, so far as can be seen from preliminary studies (Bramwell, 1961), the diets in the two occupations are remarkably similar. Further speculation about the extent to which the differences in physique are due to differences in the occupation of driving as compared with that of conducting, or are present when the men join because different sorts of men choose different sorts of work and then do different things-i.e. the question of constitutional factors in relation to environment, can be postponed because further information is now being gathered. It is likely that both effects are at work. Meanwhile the important point is not "How does the difference in physique arise?", but "Is the difference big enough to explain the difference in coronary disease?". Table IX shows that, in respect of sudden death at least, and here the occupational difference is clearest, the difference in mortality remains substantial even when men of similar physique are compared, so that, though differences in physique may account for a small part of the difference in mortality, they do not come near to explaining it.

The technique of classification of physique in terms of uniform size has now been validated by direct comparison with clinical measurements in the same individuals. The agreement between the two types of measure was shown to be good enough for epidemiological purposes where the main emphasis is on contrasting the results for men at opposite ends of the scales of measurement. As important in the present context is the fact that there was no bias in the issuing of uniforms which might be related to the different work of conducting and driving. The main advantages of the method are twofold. It is easy-a purely clerical procedure - to get information about large, complete populations; and the information about the sick members of the populations refers to measurements made before the onset of clinical disease-a particularly important point in coronary heart disease, where some 30 per cent. die early in their first clinical attack (Morris and others, 1952, 1953). Moreover, any wasting or other change in physique, which occurs as a result of the disease, does not affect the measurements. In fact the method has some of the advantages of the prospective method of study while retaining some of the practical advantages, such as speed and cheapness, of the retrospective study. Since information can be obtained for complete populations, different populations can be compared or, because data are available for the population at risk, incidence, mortality, and prevalence rates can be calculated within a population. In the present paper, samples of the population were used to estimate rates.

The data in this paper which compare the physique of men with and without coronary heart disease are, of course, limited. They relate to simple measures of circumference of chest and waist and to height, weight, and body fat, the subtleties of somatotyping being missed. The comparison of sudden death rates in Table IX has, however, the great advantage of referring to all such deaths arising in a defined population group in a defined period. In representativeness, therefore, these figures make up for lack of subtlety and precision and the result is clear. The suggestion in Table IX that "medium" men-those who are neither "thin" nor "fat"-have the lowest sudden death rates, i.e. that it is not necessarily the thin ones who have the best prospects of escaping the disease, is interesting, but must be regarded as no more than a hint and a reminder that it is premature to assume that the relationship between physique and coronary heart disease is simple.

\section{SUMMARY}

(1) The rate of occurrence of first clinical attacks of coronary heart disease for the 4 years 1949-50 and $1955-56$ is shown for the men aged 35-64 who 
worked on London's double-decker buses, trams, and trolley-buses. Conductors had a lower rate than drivers when all clinical manifestations of the disease were considered together, but they had a higher rate for attacks presenting as angina pectoris, particularly in the older age groups.

(2) "Sudden death" rates from coronary heart disease as the first clinical manifestation are shown for the 10 years 1949-58. Conductors had one-third the rates of drivers under 50 years of age and twothirds of the rates at ages over 50 .

(3) The physique of conductors was compared with that of drivers by comparing the sizes of their uniforms. In terms of the waist measurement of the trousers and the chest measurement of the jacket, conductors had a smaller girth than drivers at every age from 25-64. The data were obtained for all the men of the appropriate age on the books of thirteen bus garages and tram and trolley-bus depots, on certain specified days. The differences in physique between conductors and drivers at ages 40-64 were confirmed by direct measurement of samples of men. Skinfold measurements of conductors were also shown to be smaller than those of drivers.

(4) Uniform measurements were compared with clinical measurements in the same men. The uniform measurements were, of course, bigger but correlations between the two waist measurements were 0.88 for conductors and 0.86 for drivers, and between chest measurements 0.75 for conductors and 0.78 for drivers. There appeared to be no bias towards issuing drivers with garments that fitted more loosely because of the nature of their work.

(5) A comparison in terms of uniform size between conductors, drivers who started work as conductors, and drivers recruited directly as such, showed that the drivers who had been conductors were intermediate between the other two groups at every age from 25-64.

(6) Comparison of the clinical waist and chest measurements of men who had survived an attack of coronary heart disease and controls matched for age, job, length of service, and place of work showed no significant difference between patients and controls; nor did comparisons of height, weight, or ponderal index show any significant difference.
(7) A comparison of the skinfold measurements of men who had had an attack of coronary heart disease and these matched controls showed significantly greater measurements for patients than for controls in conductors, but not in drivers.

(8) Sudden death rates of conductors and drivers in two age groups and three categories of trouserwaist measurements were estimated. In each of the six possible comparisons, the sudden death rate for conductors was lower than that for drivers.

(9) Conductors are thus less liable than drivers to develop coronary heart disease and in particular to die suddenly from the disease. They measure less round the waist and chest than drivers, even when young. There is no clear relationship between the chance of developing coronary heart disease, or of dying from it, and the measures of physique used (with the possible exception of skinfold measurement). The difference between conductors and drivers in the sudden death rates cannot be explained by differences between the two occupations in physique as measured by uniform size.

We are very grateful to our colleagues in the London Transport Executive, particularly Dr. L. G. Norman, Chief Medical Officer, and Mr. C. J. Cornwall, Staff Administration Officer, and in the Social Medicine Research Unit, particularly Mrs. P. Parker and Miss M. Cayford (Computers), for much help.

\section{REFERENCES}

Acheson, R. M. (1961). Brit. J. prev. soc. Med., 15, 49.

Bramwell, E. M. (1961). Proc. Nutr. Soc., 20, 30.

Bronte-Stewart, B. (1959). Postgrad. med. J., 35, 180.

Kagan, A. (1960). Proc. roy. Soc. Med., 53, 18.

Keys, A. (1957). J. Amer. med. Ass., 164, 1912.

Morris, J. N. (1957). "Uses of Epidemiology". Livingstone, Edinburgh.

(1959). Arch. intern. Med., 104, 903.

and Crawford, M. D. (1958). Brit. med. J., 2, 1485. , Heady, J. A., and Barley, R. G. (1952). Ibid., 1, 503.

,- , and Raffle, P. A. B. (1956). Lancet, 2, 569.

, Roberts, C. G., and Parks, J. W. (1953). Ibid., 2, 1053, 1111.

and Raffle, P. A. B. (1954). Brit. J. industr. Med., 11, 260.

Reid, D. D. (1958). Proctitioner, 180, 184.

Rosenman, R. H., and Friedman, M. (1958). Calif. Med., 89, 169.

Sanders, K. (1959). Lancet, 2, 432.

World Health Organization (1959). Techn. Rep. Ser. No. 164. W.H.O., Geneva. 